\title{
Direct gamma-ray measurement of different radionuclides in the surface water of Suez Canal
}

\author{
Y.F. LASHEEN ${ }^{1}$, T. EL-ZAKLA ${ }^{1}$, A.F. SELIMAN ${ }^{1}$, A.A. ABDEL-RASSOUL ${ }^{1}$
}

(Manuscript received 27 June 2007, accepted 4 January 2008)

ABSTRACT The radioactivity levels of naturally-occurring ${ }^{238} \mathrm{U},{ }^{232} \mathrm{Th},{ }^{226} \mathrm{Ra}$ and ${ }^{40} \mathrm{~K}$ and anthropogenic ${ }^{137} \mathrm{Cs}$ in surface water from eight locations in the Suez Canal have been assessed by gamma-ray spectrometry. The samples were further characterized by determination of the common cations and anions using ion chromatography. $\mathrm{A}$ comparison of ${ }^{137} \mathrm{Cs}$ radioactivity levels in surface water from the Suez Canal with those of other sea waters is presented. The radioactivity levels of ${ }^{238} \mathrm{U},{ }^{232} \mathrm{Th},{ }^{226} \mathrm{Ra}$ and ${ }^{40} \mathrm{~K}$ from sea water are also reported. The effect of total dissolved solids (TDS), chloride, sulphate ion concentrations on the radioactivity levels of ${ }^{238} \mathrm{U},{ }^{232} \mathrm{Th}$ and ${ }^{226} \mathrm{Ra}$ is discussed.

Keywords: gamma ray measurements / radionuclides / Suez canal

RÉSUMÉ Mesure directe du rayonnement gamma émis par divers radionucléides dans les eaux de surface du canal de Suez.

Par spectrométrie gamma, nous avons évalué les niveaux de radioactivité de ${ }^{238} \mathrm{U}$, ${ }^{232} \mathrm{Th},{ }^{226} \mathrm{Ra}$ et ${ }^{40} \mathrm{~K}$ d'origine naturelle, ainsi que de ${ }^{137} \mathrm{Cs}$ anthropogénique, dans l'eau de surface, en huit emplacements sur le canal de Suez. Nous avons ensuite caractérisé les échantillons en déterminant, par chromatographie ionique, les cations et anions communs. Nous comparons, ici, les niveaux de radioactivité de ${ }^{137} \mathrm{Cs}$ dans l'eau de surface du canal de Suez, à ceux dans d'autres eaux maritimes. Nous donnons aussi les niveaux de radioactivité de ${ }^{238} \mathrm{U},{ }^{232} \mathrm{Th},{ }^{226} \mathrm{Ra}$ et ${ }^{40} \mathrm{~K}$ dans l'eau de mer. Nous étudions l'effet des concentrations d'ions chlorure et sulfate, venant de solides totalement dissous (STD), sur les niveaux de radioactivité de ${ }^{238} \mathrm{U},{ }^{232} \mathrm{Th}$ et ${ }^{226}$ Ra.

\section{Introduction}

Suez Canal lies within the northeastern area of Egypt and connects the Mediterranean Sea to the Gulf of Suez and thus to the Red Sea, extending from Port Said in the north to Port Tawfiq, near Suez, in the south. It is $165 \mathrm{~km} \mathrm{long,}$ and passes through an area of considerable agricultural, industrial and touristic activities. The considerable amounts of international trade transported through the Suez Canal, include among others radioactive materials resulting in increasing

\footnotetext{
${ }^{1}$ Hot Labs. Center, Atomic Energy Authority, P.C. 13759, Cairo, Egypt.
} 
public concern about radiation safety during transport (Abril and Abdel-Aal, 2000). El-Tahawy et al. (1994), measured the radioactivity levels of both natural and artificial radionuclides in the stream water of Suez Canal and related bottom sediments and found that the fate of released radionuclides will strongly dependent on the chemical affinity to particulate matter in suspended loads and bottom sediments. Abril and Fraga (1996), proposed an eustrine dispersion model for nonconservative radionuclides and tried to apply it to study the dispersion of ${ }^{226} \mathrm{Ra}$ in the Odiel river area of Spain, at different spatial and temporal scale.

Among the different isotopes of uranium, ${ }^{238} \mathrm{U}$ is the predominant contributor to natural radioactivity. In the Earth's crust the average ${ }^{238} \mathrm{U}$ content has been estimated to be $2.7 \mathrm{mg} / \mathrm{kg}$, and its concentration may be as high as $120 \mathrm{mg} / \mathrm{kg}$ in phosphate rocks (Padam et al., 1996), while the average content of ${ }^{232} \mathrm{Th}$ is almost about $9.6 \mathrm{mg} / \mathrm{kg}$ (Firestone et al., 1996). Thus enhanced levels of uranium, thorium and their daughters might be present in water in areas that are rich in natural radioactivity.

Uranium isotopes $\left({ }^{238} \mathrm{U},{ }^{235} \mathrm{U}\right.$ and $\left.{ }^{234} \mathrm{U}\right)$ are known to have a non-negligible radiotoxicity (WHO, 1978; Malcome-Lawes, 1979); which several radionuclides in related radioactive decay chains of both ${ }^{238} \mathrm{U}$ and ${ }^{235} \mathrm{U}$ are highly radiotoxic. The most radiotoxic among them is radium, which is known as carcinogenic element and exists in several isotopic forms. The predominant radium isotopes are ${ }^{226} \mathrm{Ra}$, an alpha emitter with a half-life of 1600 years, and ${ }^{228} \mathrm{Ra}$, a beta emitter with a half-life of 5.8 years (Sidhu and Breithart, 1998). When radium is taken into the body, its metabolic behavior is similar to that of calcium and an appreciable fraction is deposited in bones and the remaining fraction will be distributed almost uniformly in soft tissues (Wrenn et al., 1985).

Radium concentration in surface waters normally ranges from 0.01 to $0.1 \mathrm{~Bq} / \mathrm{L}$ (Iyengar, 1990) from which the highest values have been found in waters close to uranium mining and milling sites (Benes, 1990). An important aspect of radium protection is the critical pathway being ingestion through the food chain or drinking water (Kahlos and Asikainen, 1980). In drinking water from Qena Governorate of Upper Egypt, the mean ${ }^{226} \mathrm{Ra}$ concentration is about $0.049 \pm$ $0.026 \mathrm{~Bq} / \mathrm{L}$, while in ground water from springs within Safaga and El-Quseir areas in the Red Sea region where a number of phosphate mines exist, the mean radioactivity levels of ${ }^{226} \mathrm{Ra}$ and ${ }^{232} \mathrm{Th}$ are $0.113 \pm 0.033$ and $0.051 \pm 0.022 \mathrm{~Bq} / \mathrm{L}$, respectively (Ahmed, 2004).

In the present study, several surface water samples from different locations in the Suez Canal are studied to identify the chemical characteristics of the waters and to investigate the radioactivity levels of both natural and artificial radionuclides. 


\section{Experimental}

\subsection{Samples and sample preparation}

Eight samples (1.0 L each) were collected from different areas of the Suez Canal, including samples from El Qantara, El Ballah, El Firdan, Tousson, Deversoir, El Kabrit, Geneffe and El Shallufa (Fig. 1). Each sample was prepared for $\gamma$-spectroscopic measurements by being transferred to a polyethylene Marinelli beaker with appropriate sealing. The samples were measured under the same geometrical conditions used for counting reference standards after being corrected for background. The prepared samples were measured by $\gamma$-spectrometry after a long enough storage period to allow secular equilibrium of ${ }^{238} \mathrm{U}$ and ${ }^{232} \mathrm{Th}$ and ${ }^{226} \mathrm{Ra}$ with their immediate daughters. All samples were stored seven months to assure secular equilibrium between ${ }^{238} \mathrm{U}$ with its daughter ${ }^{234} \mathrm{Th}$ (with half-life 24.1 day) and also between ${ }^{226} \mathrm{Ra}$ and its daughters $\left({ }^{214} \mathrm{~Pb}\right.$ and $\left.{ }^{214} \mathrm{Bi}\right)$. Each sample was counted for $86400 \mathrm{~s}$ to accumulate acceptable counting statistics especially when dealing with samples of low radioactivity.

\subsection{Inorganic analysis}

The physical characteristics of test samples were defined through determination of $\mathrm{pH}$, electrical conductivity (EC) and the total dissolved solids (TDS) using classical conventional methods. For simultaneous determination of the common cations including sodium, potassium, magnesium and calcium, an automated ion chromatographic system was used (type Dionex, model 2000i/sp, USA) with CS12A analytical column and methane sulphonic acid as eluent. For sulphate and chloride ions, AS12A was used as column and a solution mixture of sodium carbonate and bicarbonate as eluent (Dionex, 1995a, 1995b).

\subsection{Radioactivity measurements}

Gamma ray spectroscopic measurements are carried out with a system including a HPGe P-type detector with resolution (FWHM) at $122 \mathrm{keV} \sim 1.1 \mathrm{keV}\left({ }^{57} \mathrm{Co}\right)$ and at $1332 \mathrm{keV} \sim 2.0 \mathrm{keV}\left({ }^{60} \mathrm{Co}\right)$. The relative efficiency at $1.33 \mathrm{MeV}$ is $30 \%$. The detector is shielded with $100 \mathrm{~mm}$ thick lead with inner lining of $3 \mathrm{~mm}$ thick copper and $3 \mathrm{~mm}$ thick cadmium sheet. The germanium crystal is operated at $3000 \mathrm{~V}$ and is dipped in a Dewar filled with liquid nitrogen used for cooling and set of several radioactive standards of known gamma energy lines are used for energy calibration, including ${ }^{22} \mathrm{Na}$ with $E_{\gamma}=511 \mathrm{keV},{ }^{137} \mathrm{Cs} E_{\gamma}=661 \mathrm{keV},{ }^{60} \mathrm{Co} E_{\gamma}=$ $1332 \mathrm{keV}$ and $1173 \mathrm{keV},{ }^{57} \mathrm{Co} E_{\gamma}=122 \mathrm{keV},{ }^{133} \mathrm{Ba} E_{\gamma}=356 \mathrm{keV}$ (main gamma 
Y.F. LASHEEN et al.

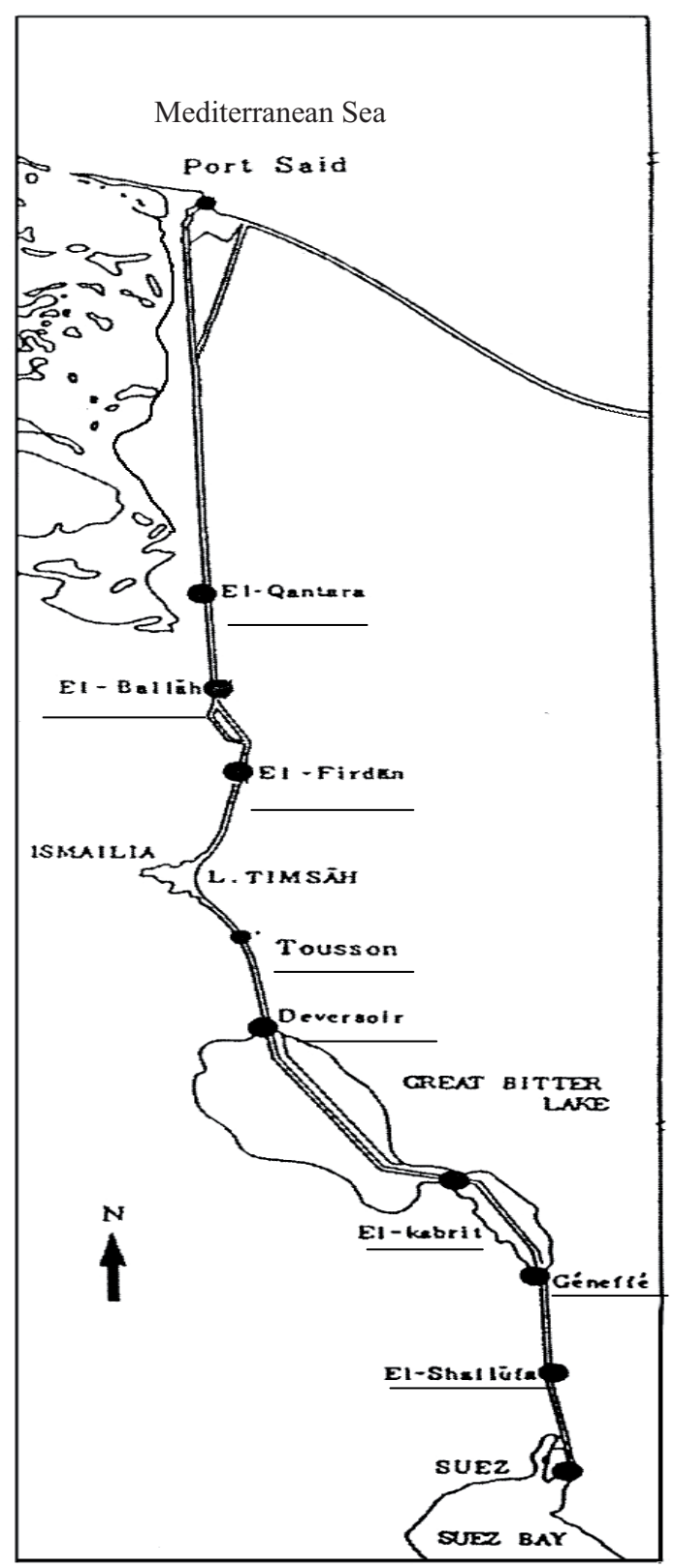

Figure 1 - Different sampling locations within Suez Canal.

Les différents emplacements de prélèvements, sur le canal de Suez. 
line). For efficiency calibration, a $1.0 \mathrm{~L}$ volume of standard water source kept in Marinelli beaker is used as reference material containing known amount of natural uranium supplied from IAEA, and the background level is determined by using 1.0 liter of de-ionized water measured under the same geometrical condition. The measured spectra are evaluated using the computer software Genie 2000.

The choice of $\gamma$-ray lines for the assessment of both ${ }^{238} \mathrm{U}$ and ${ }^{226} \mathrm{Ra}$ has been reported by some workers. Shawky et al. (2001), used gamma spectroscopy for characterizing naturally occurring radioactive materials (NORM) in oil industries from the Eastern and Western Deserts of Egypt. For the different nuclides in ${ }^{238} \mathrm{U}$ decay series, different gamma energy lines are used, including the $63.29 \mathrm{keV} \gamma$-line of ${ }^{234} \mathrm{Th}$, the $186 \mathrm{keV}$ line of ${ }^{226} \mathrm{Ra}$ after considering the $186.7 \mathrm{keV}$ of ${ }^{235} \mathrm{U}$ if present, the $295.1 \mathrm{keV} \gamma$-line and $351.6 \mathrm{keV}$ energy line of ${ }^{214} \mathrm{~Pb}$, the $609 \mathrm{keV}$ line, $768 \mathrm{keV}, 934 \mathrm{keV}$ and $1120 \mathrm{keV}$ of ${ }^{214} \mathrm{Bi}$. Bruzzi et al. (2000) also determined the radioactivity level of uranium decay series in raw materials and in end of products of the Italian ceramics industry. The areas of the peaks that selected including the three photopeaks of ${ }^{214} \mathrm{Bi}(609 \mathrm{keV}, 1120 \mathrm{keV}$ and $1764 \mathrm{keV})$ and the two photopeaks of ${ }^{214} \mathrm{~Pb}$ (295 keV and $\left.351.6 \mathrm{keV}\right)$. Also, Ronald (1998) developed a method for rapid determination of the radioactivity levels of uranium in NORM by gamma spectroscopy. The number of counts related to the above major photopeaks is used to calculate the concentration of ${ }^{238} \mathrm{U}$, while ${ }^{226} \mathrm{Ra}$ was determined through the average activity of daughters ${ }^{214} \mathrm{Bi}$ and ${ }^{214} \mathrm{~Pb}$.

In the present work, the radioactivity level of ${ }^{238} \mathrm{U}$ in test samples is determined by measurements based on the intensity and efficiency of $63.29 \mathrm{keV}$ $\left(I_{\gamma}=3.83 \%\right)$ and $92.8 \mathrm{keV}\left(I_{\gamma}=5.42 \%\right) \gamma$-lines of the first daughter ${ }^{234} \mathrm{Th}$ respecting that there is no secular equilibrium between ${ }^{238} \mathrm{U}$ and ${ }^{226} \mathrm{Ra}$. The relative intensities $I_{\gamma}$ (gamma-line probabilities) of each radionuclide are listed in technical report series No. 295 (IAEA, 1989).

The mean radioactivity level of ${ }^{226} \mathrm{Ra}$ in test samples are determined by measurements based on the intensity and efficiency of $295 \mathrm{keV}\left(I_{\gamma}=19.7 \%\right)$ and $351.6 \mathrm{keV}\left(I_{\gamma}=38.9 \%\right) \gamma$-lines of the daughter ${ }^{214} \mathrm{~Pb}$ respective of secular equilibrium as well as by measurements based on $\gamma$-line $609.3 \mathrm{keV}\left(I_{\gamma}=43.3 \%\right)$ of ${ }^{214} \mathrm{Bi}$ daughter, while the radioactivity level of ${ }^{226} \mathrm{Ra}$ can not be determined (unless necessary correction at $186 \mathrm{keV} \gamma$-line) because of spectral interference and the contribution of ${ }^{235} \mathrm{U}$ at the same line.

Figure 2 illustrates a typical gamma ray spectrum including the gamma energy lines with respective radionuclides referring to El Ballah water sample. 


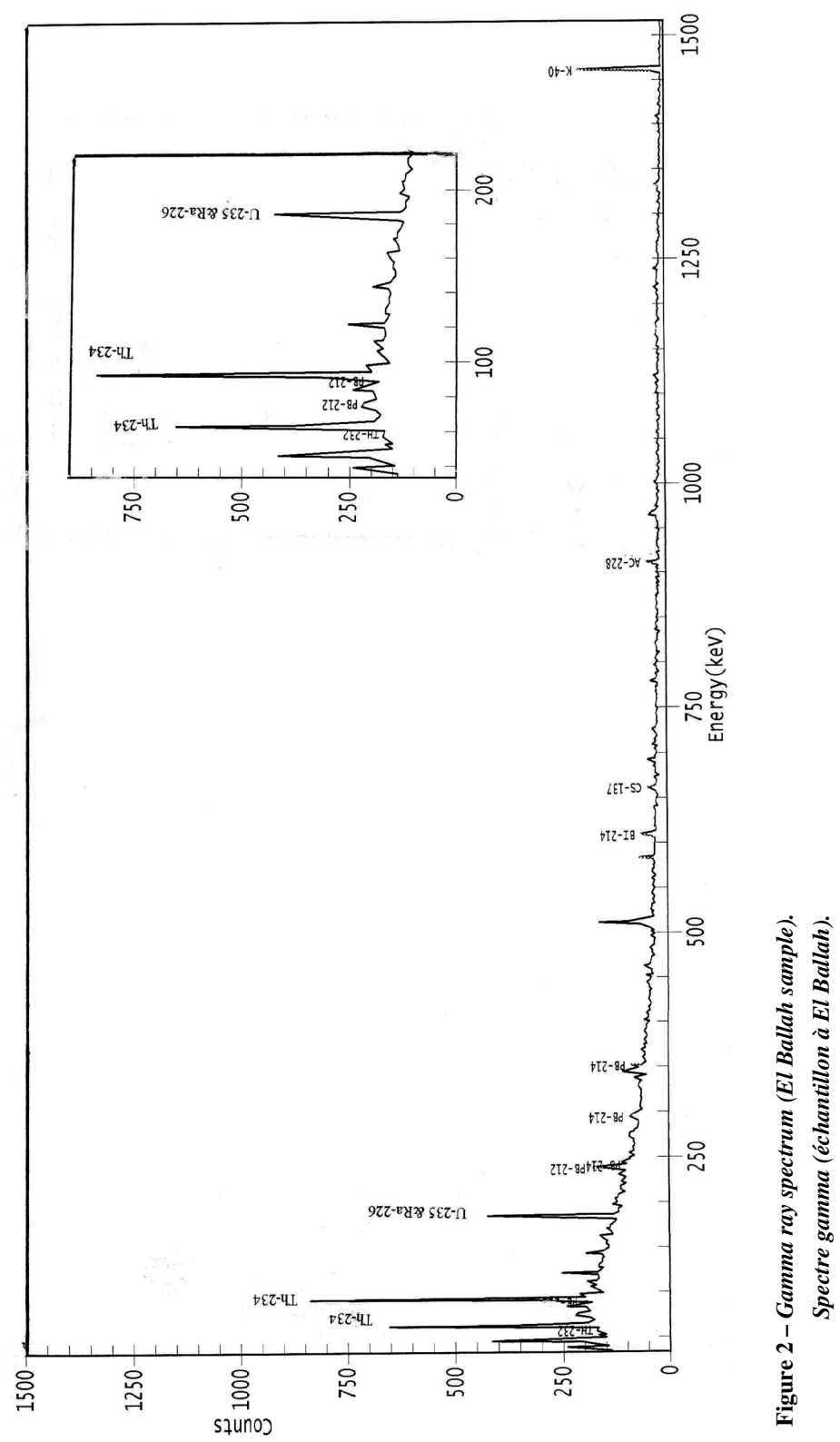


The ${ }^{226}$ Ra activity of drinking and non drinking water samples was determined through the intensity of $351.9 \mathrm{keV}$ and $609.3 \mathrm{keV}$ gamma lines of ${ }^{214} \mathrm{~Pb}$ and ${ }^{214} \mathrm{Bi}$ respectively. Several gamma lines of ${ }^{214} \mathrm{~Pb}$ and ${ }^{214} \mathrm{Bi}$ were also monitored (Ahmed, 2004).

For the measurement of relatively high levels of radium, $\gamma$-spectrometry has been employed using a germanium semiconductor detector. The procedure is limited to the determination of ${ }^{226} \mathrm{Ra}$ and ${ }^{228} \mathrm{Ra}\left({ }^{228} \mathrm{Ac}\right)$. It involves timeconsuming equilibration between ${ }^{226} \mathrm{Ra}$ and its ${ }^{214} \mathrm{Bi}$ daughter. The distribution of ${ }^{214} \mathrm{Bi}$ and ${ }^{228} \mathrm{Ac}$ must be homogeneous throughout the sample, and the standard must have the same configuration and density as the sample. Neither of the above two criteria are necessarily easily achieved. Alternatively, it is possible to measure ${ }^{226} \mathrm{Ra}$ directly using the $186 \mathrm{keV}$ line. However, the $\gamma$-emission probability is relatively low and is liable to interfere with ${ }^{235} \mathrm{U}$ (Jia et al., 2006).

Referring to the above concern, an empirical equation can be assumed and applied to overcome interference of both ${ }^{235} \mathrm{U}$ with relative intensity $\left(I_{\gamma}=57.5 \%\right)$ and ${ }^{226} \mathrm{Ra}$ with relative intensity $\left(I_{\gamma}=3.6 \%\right)$. The following formula is mainly depending two essential conditions.

\section{Condition 1}

If the net count rate of ${ }^{235} \mathrm{U}$ is detectable at energy line $143.6 \mathrm{keV}$ with relative intensity $\left(I_{\gamma}=10.9 \%\right)$ and/or $163.3 \mathrm{keV}$ with relative intensity $\left(I_{\gamma}=5.0 \%\right)$. The empirical formula can be assumed as following:

$$
A\left({ }^{226} \mathrm{Ra}\right) E 186=\left[C_{T}-C\left({ }^{235} \mathrm{U}\right) E 186\right] / I_{\gamma}\left({ }^{226} \mathrm{Ra}\right) E 186 \varepsilon_{(E 186)}
$$

where:

$A\left({ }^{226} \mathrm{Ra}\right) E 186$ is the net radioactivity level of ${ }^{226} \mathrm{Ra}$ at energy line $186 \mathrm{keV}$,

$C_{T}$ is the net total count rate of both ${ }^{235} \mathrm{U}$ and ${ }^{226} \mathrm{Ra}$ at gamma energy line $186 \mathrm{keV}$,

$I_{\gamma}\left({ }^{226} \mathrm{Ra}\right)$ is the ${ }^{226} \mathrm{Ra}$ relative intensity $\left(I_{\gamma}=3.6 \%\right)$ at energy line $186 \mathrm{keV}$,

$\varepsilon_{(E 186)}$ is the counting efficiency at gamma energy line $186 \mathrm{keV}$,

$C\left({ }^{235} \mathrm{U}\right) E 186$ is the net count rate of ${ }^{235} \mathrm{U}$ (only) at gamma energy line $186 \mathrm{keV}$. This item $\left(C\left({ }^{235} \mathrm{U}\right) E 186\right)$ can be calculated as follow:

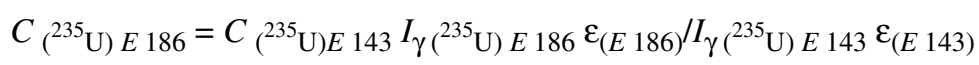


where:

$C\left({ }^{235} \mathrm{U}\right) E 143$ is the net count rate of ${ }^{235} \mathrm{U}$ at gamma energy line $143 \mathrm{keV}$,

$I_{\gamma}\left({ }^{235} \mathrm{U}\right) E 186$ is the ${ }^{235} \mathrm{U}$ relative intensity $\left(I_{\gamma}=57.5 \%\right)$ at energy line $186 \mathrm{keV}$,

$I_{\gamma}\left({ }^{235} \mathrm{U}\right) E 143$ is the ${ }^{235} \mathrm{U}$ relative intensity $\left(I_{\gamma}=10.9 \%\right)$ at energy line $143 \mathrm{keV}$,

$\varepsilon_{(E 143)}$ is the counting efficiency at gamma energy line $143 \mathrm{keV}$.

\section{Condition 2}

If the net count rate of ${ }^{235} \mathrm{U}$ is not detectable or below detection limit at energy line 143.6 and/or $163.3 \mathrm{keV}$, the empirical formula can be applied as equation (1) by assuming that the radioactivity level of ${ }^{226} \mathrm{Ra}$ at $\gamma$-energy line $186 \mathrm{keV}$ is equal to average value that calculated at $295.2,351.5$ and $609.8 \mathrm{keV}$ of ${ }^{226} \mathrm{Ra}$ daughters $\left({ }^{214} \mathrm{~Pb}\right.$ and $\left.{ }^{214} \mathrm{Bi}\right)$ respecting to secular equilibrium as follow:

$$
A\left({ }^{226} \mathrm{Ra}\right) E 186=A\left({ }^{226} \mathrm{Ra}\right) E 295, E 351, E 609 .
$$

In this case, referring to equation (1) by knowing the total net count rate that can easily be measured at $186 \mathrm{keV}$ gamma energy line and the radioactivity level of ${ }^{226}$ Ra referring to equation (2), the net and pure count rate of ${ }^{235} \mathrm{U}$ only at the same gamma line and hence the radioactivity level of ${ }^{235} \mathrm{U}$ can be determined without spectral interference with ${ }^{226} \mathrm{Ra}$ (Tab. I).

TABLE I

Determination of radioactivity levels of both naturally and anthropogenic radionuclides in Suez canal water samples.

Détermination des niveaux totaux de radioactivité dus aux radionucléides naturels et anthropogéniques.

\begin{tabular}{lcccccc}
\hline & \multicolumn{5}{c}{ Radionuclides } \\
\cline { 2 - 7 } Sample & ${ }^{238} \mathrm{U}$ & ${ }^{235} \mathrm{U}$ & ${ }^{226} \mathrm{Ra}$ & ${ }^{232} \mathrm{Th}$ & ${ }^{40} \mathrm{~K}$ & ${ }^{137} \mathrm{Cs}$ \\
\cline { 2 - 7 } & \multicolumn{5}{c}{ Radioactivity level, $\mathrm{Bq} / \mathrm{L}$} \\
\hline El Qantara & $1.24 \pm 0.052$ & $0.061 \pm 0.005$ & $0.093 \pm 0.013$ & $0.122 \pm 0.011$ & $3.20 \pm 0.260$ & $0.037 \pm 0.006$ \\
El Ballah & $1.47 \pm 0.058$ & $0.068 \pm 0.005$ & $0.077 \pm 0.005$ & $0.118 \pm 0.010$ & $2.71 \pm 0.242$ & $0.046 \pm 0.007$ \\
El Firdan & $1.88 \pm 0.066$ & $0.090 \pm 0.006$ & $0.082 \pm 0.006$ & $0.106 \pm 0.010$ & $3.02 \pm 0.245$ & $0.038 \pm 0.006$ \\
Tousson & $1.16 \pm 0.050$ & $0.058 \pm 0.005$ & $0.065 \pm 0.006$ & $0.163 \pm 0.013$ & $3.58 \pm 0.283$ & b.d \\
Deversoir & $1.26 \pm 0.053$ & $0.070 \pm 0.005$ & $0.060 \pm 0.008$ & $0.130 \pm 0.012$ & $3.09 \pm 0.260$ & $0.048 \pm 0.007$ \\
El Kabrit & $1.81 \pm 0.063$ & $0.090 \pm 0.006$ & $0.068 \pm 0.005$ & $0.173 \pm 0.013$ & $4.17 \pm 0.301$ & $0.036 \pm 0.007$ \\
Geneffe & $1.42 \pm 0.055$ & $0.065 \pm 0.005$ & $0.078 \pm 0.006$ & $0.112 \pm 0.009$ & $3.40 \pm 0.264$ & $0.030 \pm 0.006$ \\
El Shallufa & $1.13 \pm 0.048$ & $0.054 \pm 0.005$ & $0.092 \pm 0.006$ & $0.105 \pm 0.010$ & $2.51 \pm 0.230$ & $0.038 \pm 0.006$ \\
average & $\mathbf{1 . 2 7} \pm \mathbf{0 . 0 2 0}$ & $\mathbf{0 . 0 6 9} \pm \mathbf{0 . 0 0 2}$ & $\mathbf{0 . 0 7 7} \pm \mathbf{0 . 0 0 2}$ & $\mathbf{0 . 1 2 9} \pm \mathbf{0 . 0 0 4}$ & $\mathbf{3 . 2 1 0} \pm \mathbf{0 . 0 9 2}$ & $\mathbf{0 . 0 3 9} \pm \mathbf{0 . 0 0 2}$
\end{tabular}


In the present work, the calculated radioactivity level of ${ }^{235} \mathrm{U}$ is according to the empirical formula (1) with condition (2) and this was only applied because the count rates of ${ }^{235} \mathrm{U}$ at $\gamma$-energy line 143 and $163 \mathrm{keV}$ are not detectable.

${ }^{232} \mathrm{Th}$ mean activity was measured through the $\gamma$-line of their daughters at $238.7 \mathrm{keV}\left(I_{\gamma}=44.6 \%\right)$ of ${ }^{212} \mathrm{~Pb}$, and at $584 \mathrm{keV}\left(I_{\gamma}=30.7 \%\right)$ of ${ }^{208} \mathrm{Tl}$ and ${ }^{228} \mathrm{Ac}$ at $911.21 \mathrm{keV}$ with intensity $26.6 \%$. For ${ }^{40} \mathrm{~K}$ through the $1460.75 \mathrm{keV} \gamma$-line with intensity $10.7 \%$, and ${ }^{137 \mathrm{~m}} \mathrm{Ba}\left({ }^{137} \mathrm{Cs}\right)$ through the $661 \mathrm{keV} \gamma$-line with the intensity of $85 \%$.

\section{Results and discussion}

\subsection{Radioactivity determination}

The Suez Canal, being a man-made waterways, is characterized by limited water recharge rates and is subject to probable chemical and radioactive contamination from several shipments passing daily through the Canal. This high residence periods for contaminants and resulting concentrations in Suez Canal water would not comparable to samples from open seas. In the present work, the radioactivity of ${ }^{238} \mathrm{U},{ }^{235} \mathrm{U},{ }^{226} \mathrm{Ra},{ }^{232} \mathrm{Th},{ }^{40} \mathrm{~K}$ and ${ }^{137} \mathrm{Cs}$ in surface water samples from different locations in the Suez Canal are given in Table I. The range of radioactivity of ${ }^{238} \mathrm{U}$ is from $1.13 \pm 0.048$ ( $\mathrm{El}$ Shallufa area) to $1.88 \pm 0.066 \mathrm{~Bq} / \mathrm{L}$ ( $\mathrm{El}$ Firdan area) with an average for the eight samples of $1.27 \pm 0.02 \mathrm{~Bq} / \mathrm{L}$ along the canal, while for ${ }^{235} \mathrm{U}$, the calculated radioactivity level according to the empirical formula in experimental is within average $0.069 \pm 0.002 \mathrm{~Bq} / \mathrm{L}$ giving a ${ }^{235} \mathrm{U} /{ }^{238} \mathrm{U}$ average ratio $0.049 \pm 0.002$, (Tab. II). This seems to be convenient with the calculated ratio $(0.045)$ of naturally occurring, regarding the isotopic composition and decay constant of each. This gives a significant support to the empirical formula that was applied to calculate the radioactivity level of ${ }^{235} \mathrm{U}$. For ${ }^{226} \mathrm{Ra}$, the average range of radioactivity levels is $0.077 \pm 0.002 \mathrm{~Bq} / \mathrm{L}$ giving a ${ }^{226} \mathrm{Ra} /{ }^{238} \mathrm{U}$ average ratio $0.056 \pm 0.002$ as illustrated in Table II, and this reveals the disequilibrium between ${ }^{226} \mathrm{Ra}$ and ${ }^{238} \mathrm{U}$ and this may due to the difference in chemical behavior.

For ${ }^{232} \mathrm{Th}$, the average radioactivity in the analyzed samples is $0.129 \pm$ $0.004 \mathrm{~Bq} / \mathrm{L}$, giving an average ${ }^{232} \mathrm{Th} /{ }^{238} \mathrm{U}$ ratio of $0.093 \pm 0.003 .{ }^{232} \mathrm{Th}$ levels are obviously lower than those of ${ }^{238} \mathrm{U}$ in all samples, which may be due to a greater leaching of ${ }^{238} \mathrm{U}$ in different aquatic media. As for ${ }^{40} \mathrm{~K}$, the range of its radioactivity lies from $2.51 \pm 0.23 \mathrm{~Bq} / \mathrm{L}$ in the El Shallufa area to $4.17 \pm 0.30 \mathrm{~Bq} / \mathrm{L}$ in samples from El Kabrit location, within an average of $3.21 \pm 0.092 \mathrm{~Bq} / \mathrm{L}$. For ${ }^{137} \mathrm{Cs}$, the range of radioactivity levels in all samples lie within an average around $0.039 \pm 0.002 \mathrm{~Bq} / \mathrm{L}$, and proved to be, if present, below detection limits in samples from Tousson location. 


\section{TABLE II}

Determination of radioactivity ratios of naturally occurring radionuclides in Suez canal water samples.

Détermination des rapports de radioactivité des radionucléides d'origine naturelle dans les échantillons d'eau du canal de Suez.

\begin{tabular}{lccc}
\hline & \multicolumn{3}{c}{ Radionuclides } \\
\cline { 2 - 4 } Sample location & ${ }^{235} \mathrm{U} /{ }^{238} \mathrm{U}$ & ${ }^{232} \mathrm{Ra} /{ }^{238} \mathrm{Th} /{ }^{238} \mathrm{U}$ \\
\cline { 2 - 4 } & $0.049 \pm 0.005$ & $0.075 \pm 0.011$ & $0.098 \pm 0.01$ \\
\hline El Qantara & $0.046 \pm 0.004$ & $0.052 \pm 0.004$ & $0.080 \pm 0.007$ \\
El Ballah & $0.048 \pm 0.004$ & $0.044 \pm 0.004$ & $0.056 \pm 0.006$ \\
El Firdan & $0.050 \pm 0.005$ & $0.056 \pm 0.006$ & $0.140 \pm 0.013$ \\
Tousson & $0.055 \pm 0.005$ & $0.048 \pm 0.007$ & $0.103 \pm 0.01$ \\
Deversoir & $0.050 \pm 0.004$ & $0.037 \pm 0.003$ & $0.095 \pm 0.008$ \\
El Kabrit & $0.046 \pm 0.004$ & $0.055 \pm 0.005$ & $0.079 \pm 0.007$ \\
Geneffe & $0.048 \pm 0.005$ & $0.081 \pm 0.006$ & $0.093 \pm 0.01$ \\
El Shallufa & $\mathbf{0 . 0 4 9} \pm \mathbf{0 . 0 0 2}$ & $\mathbf{0 . 0 5 6} \pm \mathbf{0 . 0 0 2}$ & $\mathbf{0 . 0 9 3} \pm \mathbf{0 . 0 0 3}$ \\
\hline average & & &
\end{tabular}

\subsection{Comparison between the activity of ${ }^{137} \mathrm{Cs}$ in Suez Canal surface water and other seas of related countries}

A comparison study between the radioactivity levels of ${ }^{137} \mathrm{Cs}$ in surface waters from Suez Canal and other related seas in different countries revealed a wide range comparable with the present work. Table III illustrates the distribution of ${ }^{137} \mathrm{Cs}$ in different wide regions including seas and oceans. This data were recently collected from reported references.

\subsection{Comparison between the activity of naturally occurring radionuclides in Suez Canal surface water and other related Seas}

Uranium radioactivity levels in Sea water have been reported by several authors (see Tab. IV). Uranium in Sea water is separated by froth flotation and determined by neutron activation or spectrophotometric method using the uranium (IV) Arsenazo III complex. Results of the analysis of Pacific coastal samples by the two methods are in good agreement; an average value of $3.0 \mu \mathrm{g} / \mathrm{L}(0.036 \mathrm{~Bq} / \mathrm{L})$, (Keiichi, 1975).

Cuculic et al. (2006) found the concentration of uranium in Sea water of Krka river estuary is ranged from $2.1 \pm 0.2$ to $3.1 \pm 0.2 \mu \mathrm{g} / \mathrm{L}(0.025-0.037 \mathrm{~Bq} / \mathrm{L})$. 


\section{TABLE III}

Comparison of ${ }^{137} \mathrm{Cs}$ activity in Suez canal surface water with other sea waters. Comparaison de l'activité de ${ }^{137}$ Cs dans l'eau de surface du canal de Suez à celle dans d'autres eaux maritimes.

\begin{tabular}{|c|c|c|}
\hline Location & ${ }^{137} \mathrm{Cs}(\mathrm{Bq} / \mathrm{L})$ & Reference \\
\hline Suez Canal, Egypt & $0.039 \pm 0.002$ & -- \\
\hline Japan Sea & $(2.6 \pm 0.89) \times 10^{-3}$ & Ito et al., 2003 \\
\hline Pacific Ocean, Japan & $(2.8 \pm 0.5) \times 10^{-3}$ & Povinec et al., 2004 \\
\hline Hong Kong Sea Water & b.d ${ }^{*}$ & HKO, 2003 \\
\hline \multicolumn{3}{|l|}{ Northern European Seas } \\
\hline Norwegian Sea & $3.0-28 \times 10^{-3}$ & Matishov and Matishov, 2004 \\
\hline Barents Sea & $2.0-15 \times 10^{-3}$ & Matishov and Matishov, 2004 \\
\hline White Sea & $11-15 \times 10^{-3}$ & Matishov and Matishov, 2004 \\
\hline Kara Sea & $2-12 \times 10^{-3}$ & Matishov and Matishov, 2004 \\
\hline Laptev Sea & $1-13 \times 10^{-3}$ & Matishov and Matishov, 2004 \\
\hline Greenland Sea & $1.7-5.4 \times 10^{-3}$ & Matishov and Matishov, 2004 \\
\hline Arctic Ocean & $1-15 \times 10^{-3}$ & Matishov and Matishov, 2004 \\
\hline \multicolumn{3}{|c|}{ North European Seas and English Channel } \\
\hline English Channel, General & $<4 \times 10^{-3}$ & Friedlanler et al., 2005 \\
\hline Skagerak/ Kateagat & $15-60 \times 10^{-3}$ & Friedlanler et al., 2005 \\
\hline Western English Channel & $1-3 \times 10^{-3}$ & Friedlanler et al., 2005 \\
\hline Irish Sea and Scottish waters & $10-45 \times 10^{-3}$ & Friedlanler et al., 2005 \\
\hline Irish Sea:Wylfa area Sellafield Coast & $200 \times 10^{-3}$ & Friedlanler et al., 2005 \\
\hline Irish Sea: Coastline & $2-35 \times 10^{-3}$ & Friedlanler et al., 2005 \\
\hline Irish Sea: Offshore & $9-35 \times 10^{-3}$ & Friedlanler et al., 2005 \\
\hline Baltic Sea & $50 \times 10^{-3}$ & Friedlanler et al., 2005 \\
\hline \multicolumn{3}{|l|}{ Spanish Mediterranean Sea } \\
\hline Barcelona, 1991 & $(4.7 \pm 0.2) \times 10^{-3}$ & Molero, 1992 \\
\hline Vandellos, 1991 & $(8.4 \pm 0.4) \times 10^{-3}$ & Molero, 1992 \\
\hline Mediterranean sea & $(2.14 \pm 0.52) \times 10^{-3}$ & Gasco et al., 2002 \\
\hline Atlantic Ocean & $(2.52 \pm 0.28) \times 10^{-3}$ & Gasco et al., 2002 \\
\hline Italian Mediterranean Sea & $3 \times 10^{-3}$ & Delfanti et al., 2002 \\
\hline
\end{tabular}

The uranium content of river related to Baltic Sea water originating in regions of igneous rock regions is low, averaging $0.5 \mu \mathrm{g} / \mathrm{L}(0.006 \mathrm{~Bq} / \mathrm{L})$. The uranium content of rivers from sedimentary rock regions seems higher with a maximum value found being $12.8 \mu \mathrm{g} / \mathrm{L}(0.143 \mathrm{~Bq} / \mathrm{L})$, (Koczy et al., 1957). He concluded that 
TABLE IV

Comparison between the activity levels of naturally occurring radionuclides in Suez canal surface water and other seas of related areas.

Comparaison des niveaux d'activité des radionucléides d'origine naturelle dans l'eau de surface du canal de Suez, à ceux de l'eau venant de mers connexes.

\begin{tabular}{|c|c|c|c|c|c|}
\hline \multirow[t]{2}{*}{ Country and Location } & \multicolumn{4}{|c|}{ Radioactivity level, $\mathrm{Bq} / \mathrm{L}$} & \multirow[t]{2}{*}{ References } \\
\hline & ${ }^{238} \mathrm{U}$ & ${ }^{232} \mathrm{Th}$ & ${ }^{226} \mathrm{Ra}$ & ${ }^{40} \mathrm{~K}$ & \\
\hline Suez Canal, Egypt & $1.27 \pm 0.02$ & $0.129 \pm 0.004$ & $0.077 \pm 0.002$ & $3.210 \pm 0.092$ & - \\
\hline Suez Canal, Egypt & 0.6 & - & - & 18 & El-Tahawy et al., 1994 \\
\hline Pacific Coastal & 0.036 & - & - & - & Keiichi, 1975 \\
\hline Croatian Adriatic Coast & 0.035 & - & - & - & Cuculic et al., 2006 \\
\hline River related Baltic Sea & $0.006-0.143$ & - & $0.0006-0.014$ & - & Koczy et al., 1957 \\
\hline Baltic Sea & $0.009-0.066$ & - & - & - & Koczy et al., 1957 \\
\hline Arabian Gulf & 0.192 & - & $<0.192$ & - & Kraemer, 2003 \\
\hline Sea water & 0.08 & - & 0.001 & 11.1 & IEER, 1996 \\
\hline Sea water & 0.037 & 0.002 & - & - & Choppin and Rydberg, 1980 \\
\hline Bombay Sea water & - & $0.36-2.24$ & - & - & Aqrawal and Vora 2003 \\
\hline Hong Kong & - & - & - & $11.9 \pm 1.0$ & HKO, 2003 \\
\hline
\end{tabular}

uranium is more easily leached out from sedimentary regions. The radium content of river water is not in equilibrium with uranium, amounting to only $10 \%$ of the later. It is thus concluded that uranium is more soluble than radium. The uranium content of water from the Balic Sea is also quite variable, ranging from 0.77 to $5.9 \mu \mathrm{g} / \mathrm{L}(0.009-0.066 \mathrm{~Bq} / \mathrm{L})$. High salinity inflowing water shows $1.8 \mu \mathrm{g} / \mathrm{L}$ $(0.022 \mathrm{~Bq} / \mathrm{L})$. Surface water increases can be explained by the high uranium content of inflowing river waters; high deep water values are correlated with an oxygen deficiency. It may be assumed that the uranium (VI) is reduced to uranium (IV), forming insoluble complex compounds with organic materials. They settle slowly to the bottom and can explain the rather high uranium content of the sediment (3.2-10.3 g/g). The normal content in clays is about $2.0 \mathrm{~g} / \mathrm{g}$. Uranium can be precipitated from Sea water by a high biological activity, which is connected with oxygen deficiency. When the sedimentation is at the same time very small, the uranium content of sediment is enriched, amounting to $200 \mathrm{~g} / \mathrm{g}$ or more.

El-Tahawy et al. (1994) have measured the concentration of natural and artificial radionuclides in Suez Canal bottom sediments and stream water using a $\gamma$-spectrometer based on a HPGe detector. The activity concentrations of ${ }^{238} \mathrm{U}$ series, ${ }^{232} \mathrm{Th}$ series and ${ }^{40} \mathrm{~K}$ did not exceed $16.0,15.5$ and $500.0 \mathrm{~Bq} / \mathrm{kg}$ dry weight for sediments. The activity concentration of ${ }^{238} \mathrm{U}$ series and ${ }^{40} \mathrm{~K}$ did not exceed 0.6 and $18.0 \mathrm{~Bq} / \mathrm{L}$ for stream water. 
In the present work, the high content of uranium in Suez Canal surface water over than the reported values in sea water may be attributed to several factors, some of which are:

1. release of uranium through waste water in the recovery and production of petroleum oil and petrol;

2. presence of soil or sediment highly enriched in uranium (as phosphate);

3. the fact that the Suez Canal has a low biological activity, could lead to less precipitation of uranium than in sea water where uranium can be precipitated by high biological activity;

4. absence or lowering of reducing substances may lead to predominant presence of uranium (VI) which form soluble complex rather than uranium (IV);

5. high content of carbonate (if presented) can increase the leaching of uranium with formation of soluble carbonate complex;

6. the chemical characterization of Suez Canal water will strongly affect the uranium content;

7. the geochemical nature (clay, sand, sediment) of the Canal itself may contain a lot of uranium sources and that be easily leached to the water content.

The content of ${ }^{232} \mathrm{Th}$ in Suez Canal is also higher than the reported value but lower than Bombay Sea water and this may be related to the difference in chemical composition in the water and also related to the difference in the Geochemical nature of each and/or other related activities.

Although the content of ${ }^{226} \mathrm{Ra}$ is higher than the reported as in Table IV (except in Arabian Gulf), this may be related to beside the above factors, the high content of ${ }^{238} \mathrm{U}$ in Suez Canal may lead to presence of high activity of ${ }^{226} \mathrm{Ra}$ as daughter from uranium. The ${ }^{40} \mathrm{~K}$ content is lower than the reported as in Table IV.

\subsection{Effect of water quality on ${ }^{238} U,{ }^{232}$ Th and ${ }^{226}$ Ra levels}

The physical and chemical characteristics of water mostly affect the radioactivity levels of ${ }^{238} \mathrm{U},{ }^{232} \mathrm{Th}$ and ${ }^{226} \mathrm{Ra}$ are revealed in Table V, and shown in Figure 3.

\subsubsection{Effect physical characteristics}

The correlation between ${ }^{238} \mathrm{U}$ and ${ }^{226} \mathrm{Ra}$ radioactivity levels in salty water (Suez Canal) and related TDS concentration seems to be negative, while it seems to be positive in case of ${ }^{232} \mathrm{Th}$, showing a slight increase in the radioactivity levels by increasing TDS concentrate within a range $46-52 \mu \mathrm{g} / \mathrm{L}$, as in Figure 3 . The same trend (negative correlation) was investigated for ${ }^{226} \mathrm{Ra}$ in case of drinking water (fresh water) with TDS concentration with in a range from 0.15 to $0.4 \mu \mathrm{g} / \mathrm{L}$ (Lasheen et al., 2007). 
TABLE V

Physical and chemical characteristics of surface water from different locations in the Suez canal. Caractéristiques physiques et chimiques de l'eau de surface provenant de divers emplacements sur le canal de Suez.

\begin{tabular}{lccccccccc}
\hline Sample & $\mathrm{pH}$ & cond., $\mu \mathrm{S}$ & $\mathrm{TDS}, \mathrm{mg} / \mathrm{L}$ & $\mathrm{Na}^{+}, \mathrm{mg} / \mathrm{L}$ & $\mathrm{K}^{+}, \mathrm{mg} / \mathrm{L}$ & $\mathrm{Mg}^{2+}, \mathrm{mg} / \mathrm{L} \mathrm{Ca}^{2+}, \mathrm{mg} / \mathrm{L}$ & $\mathrm{Cl}^{-}, \mathrm{mg} / \mathrm{L}$ & $\mathrm{SO}_{4}^{2-}, \mathrm{mg} / \mathrm{L}$ \\
\hline El-Qantara & 7.36 & 61.9 & 51.25 & $13854 \pm 156$ & $513 \pm 51$ & $1786 \pm 18$ & $515 \pm 59$ & $34645 \pm 925$ & $2840 \pm 301$ \\
El-Ballah & 7.26 & 56.8 & 47.40 & $13974 \pm 264$ & $480 \pm 15$ & $1582 \pm 34$ & $488 \pm 13$ & $33956 \pm 999$ & $3018 \pm 500$ \\
El-Firdan & 7.38 & 5.0 & 46.62 & $15138 \pm 230$ & $515 \pm 24$ & $1727 \pm 16$ & $529 \pm 07$ & $33342 \pm 998$ & $2491 \pm 263$ \\
Tousson & 7.48 & 58.8 & 48.50 & $14375 \pm 363$ & $486 \pm 18$ & $1676 \pm 59$ & $525 \pm 24$ & $29108 \pm 990$ & $2420 \pm 110$ \\
Deversoir & 7.46 & 58.4 & 48.49 & $14457 \pm 216$ & $515 \pm 17$ & $1706 \pm 41$ & $525 \pm 17$ & $34902 \pm 668$ & $3164 \pm 121$ \\
El-Kbrit & 7.51 & 59.5 & 50.01 & $15321 \pm 067$ & $528 \pm 10$ & $1833 \pm 09$ & $528 \pm 10$ & $32800 \pm 418$ & $2333 \pm 030$ \\
Geneffe & 7.50 & 61.2 & 51.30 & $15262 \pm 154$ & $536 \pm 30$ & $1856 \pm 08$ & $544 \pm 09$ & $33358 \pm 893$ & $2655 \pm 214$ \\
El-Shallufa & 7.46 & 59.7 & 50.02 & $14141 \pm 120$ & $505 \pm 15$ & $1763 \pm 17$ & $521 \pm 07$ & $30205 \pm 737$ & $2563 \pm 103$ \\
\hline
\end{tabular}

\subsubsection{Effect of chemical composition}

The effect of chloride ion concentration on ${ }^{238} \mathrm{U},{ }^{226} \mathrm{Ra}$ and ${ }^{232} \mathrm{Th}$ levels was shown to significantly increase in ${ }^{238} \mathrm{U}$ and ${ }^{226} \mathrm{Ra}$ levels by increasing the chloride ion concentration range from 29 to $35 \mu \mathrm{g} / \mathrm{L}$, while at the same chloride concentrations, the ${ }^{232} \mathrm{Th}$ level decreased significantly (Fig. 3).

For ${ }^{226} \mathrm{Ra}$, the effect of chloride ion concentration on the radioactivity of radium in salty water, the correlation tends to be direct proportion with increasing the chloride iron within range from 29 to $35 \mu \mathrm{g} / \mathrm{L}$ (Fig. 3). This is consistent with the effect of chloride ion which was found be of significance only in brines or hyper saline water with chloride concentration around $5 \mu \mathrm{g} / \mathrm{L}$, (IAEA, 1990). The effect of chloride ion concentration (within range 0.005 to $0.045 \mu \mathrm{g} / \mathrm{L}$ ) on ${ }^{226} \mathrm{Ra}$ radioactivity levels in drinking water revealed a slight or negligible effect on the radioactivity level of radium (Lasheen et al., 2007).

Increasing sulphate ion concentration decreased the ${ }^{238} \mathrm{U},{ }^{226} \mathrm{Ra}$ and ${ }^{232} \mathrm{Th}$ radioactivity levels from 2.3 to $3.2 \mu \mathrm{g} / \mathrm{L}$ (Fig. 3). At this concentration range of sulphate, this trend is inconsistent with that found by (Lasheen et al., 2007), in case of radium levels in drinking water, where the effect of sulphate ions concentration proved to give almost no effect on the radioactivity levels of radium, within a concentration range from 0.001 to $0.06 \mu \mathrm{g} / \mathrm{L}$. Previous studies on the effect of water composition on radium adsorption by model solids revealed that sulphate ions if present in concentration levels typical as those in fresh water $(0.06 \mu \mathrm{g} / \mathrm{L})$ had a negligible effect (IAEA, 1990). 
DIRECT GAMMA-RAY MEASUREMENT OF DIFFERENT RADIONUCLIDES
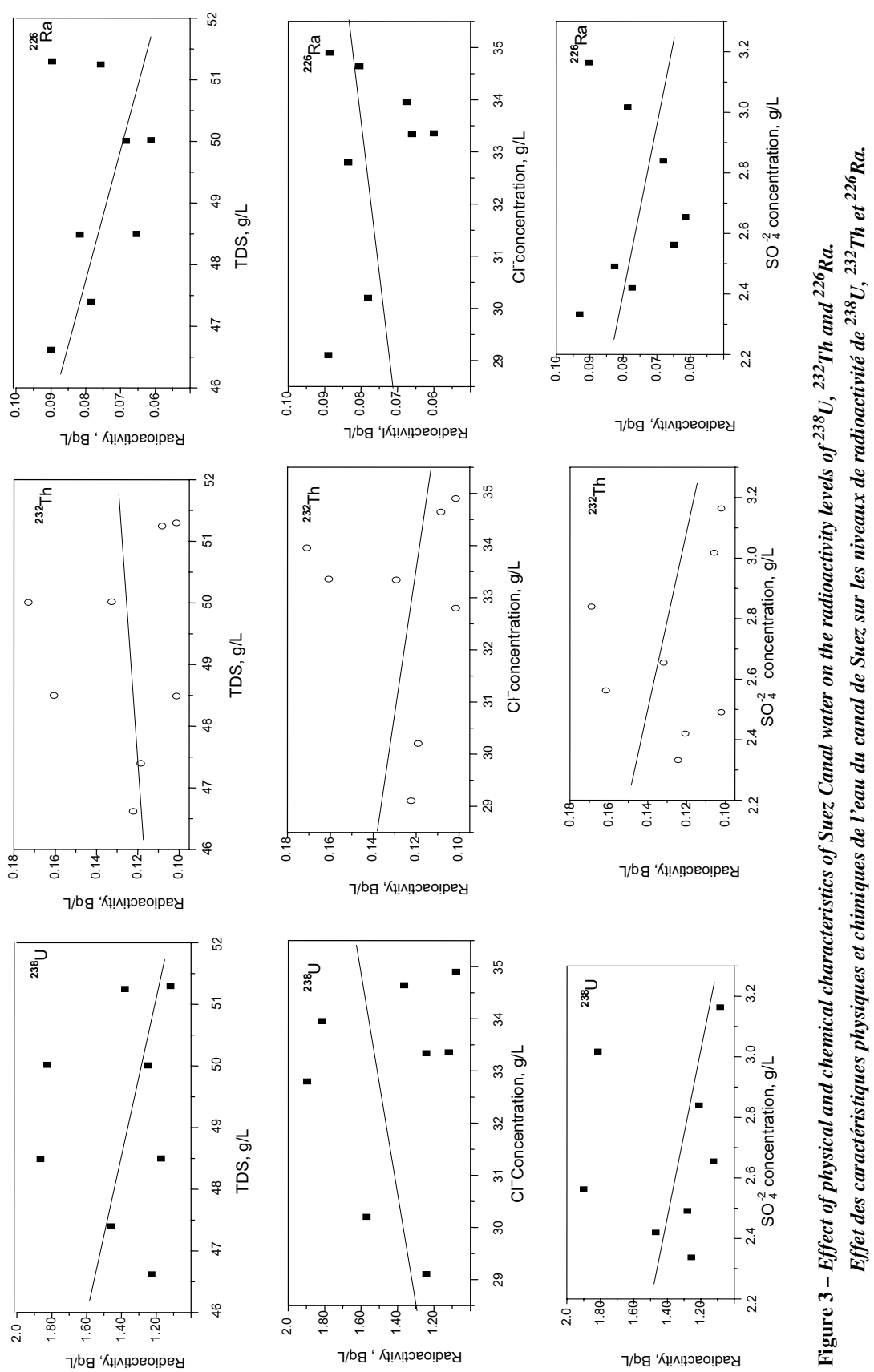

है

RADIOPROTECTION - VOL. 43 - Nº 2 (2008) 


\section{Conclusion}

It is clear that ${ }^{238} \mathrm{U}$ can be determined based on its first daughter ${ }^{234} \mathrm{Th}$ at $\gamma$-ray lines $63.29,92.8 \mathrm{keV}$ with intensities $3.83 \%$ and $5.42 \%$, respectively. This can be useful in case of direct gamma measurements respecting to the disequilibrium between ${ }^{238} \mathrm{U}$ and ${ }^{226} \mathrm{Ra}$. ${ }^{226} \mathrm{Ra}$ can be measured regarding to its relative daughters $\left[{ }^{214} \mathrm{Bi}\right.$ at gamma energy line $609.8 \mathrm{keV}\left(I_{\gamma}=43.3 \%\right)$. and ${ }^{214} \mathrm{~Pb}$ at $295.2 \mathrm{keV}\left(I_{\gamma}=\right.$ $19.7 \%)$ and $351.6 \mathrm{keV}\left(I_{\gamma}=38.9 \%\right)$ ]. A convenient results of the calculated radioactivity levels of ${ }^{235} \mathrm{U}$ based on a conditioned empirical formula revealed that this equation can be applied to overcome the spectral interference of both ${ }^{226} \mathrm{Ra}$ and ${ }^{235} \mathrm{U}$ at gamma energy line $186 \mathrm{keV}$. The natural ratio values of ${ }^{235} \mathrm{U} /{ }^{238} \mathrm{U}$ revealed a significant support for this formula.

From this study, it is also concluded that the naturally occurring radioactivity levels in Suez Canal have this order: ${ }^{40} \mathrm{~K}>{ }^{238} \mathrm{U}>{ }^{232} \mathrm{Th}>{ }^{226} \mathrm{Ra}$.

The present work could be extended to the determination of ${ }^{137} \mathrm{Cs}$ in the surface water, marine samples such as sediment to investigate the ratio of radioactivity levels related to water samples, and to biota to determine the annual dose related to food intake.

\section{REFERENCES}

Abril J.M., Fraga E. (1996) Some Physical and Chemical Features of the Variability of $k_{D}$ Distribution Coefficients for Radionuclides, J. Environ. Radioact. 30, 253-270.

Abril J.M., Abdel-Aal M.M. (2000) Marine radioactivity studies in Suez Canal. A modeling study on radionuclide dispersion, J. Environ. Radioact. 48, 279-302.

Agrawal Y.K., Vora S.B. (2003) Selective extraction and separation of thorium from monazite using n-phenylbenzo-18-crown-6-hydroxamic acid, Microchim. Acta 142, 255-261.

Ahmed N.K. (2004) Natural radioactivity of ground water in some areas of upper Egypt, Turk. J. Eng. Env. Sci. 28, 345-354.

Benes P. (1990) Radium in (Continental) surface water'. The Enviroemental Behavior of Radium, Technical Reports Series No. 310, International Atomic Energy Agency, Vienna, pp. 373-418.

Bruzzi L., Maurizio B., Giorgio M., Renato M., Serena R. (2000) Radioactivity in raw materials and end products in the Italian ceramics industry, J. Environ. Radioact. 47, 171.

Choppin G.R., Rydberg J. (1980) Naturally occurring radioactive elements and extinct radioactivity, Nuclear Chemistry, Theory and Application. Pergamon Press, pp. 234-240.

Cuculic V., Cukrov N., Barisic D., Mlakar M. (2006) Uranium in sediments, mussels (Mytilus sp.) and Sea water of the Krka river estuary, J. Environ. Radioact. 85, 59-70.

Delfanti R., Pannacciulli F.G., Papucci C. (2002) Radioactivity biomonitoring in the Italian marine environment, Mediterranean mussel watch-designing a regional program-Marseilles, CIESM Workshop Series No. 15.

Dionex (1995a) IonPac AS12A anion exchange column. Dionex Corp., Pennsylvania, USA.

Dionex (1995b) IonPac AS12A cation exchange column. Dionex Corp., Pennsylvania, USA. 
El-Tahawy M.S., Farouk M.A., Ibrahiem N.M., El-Mongey S.A.M. (1994) Natural and artificial radionuclides in the Suez Canal bottom sediments and stream water, Radiat. Phys. Chem. 44, 87-89.

Firestone B.R., Shirley S.V., Baglin M.C., Frank Chu S.Y., Zipkin, J. (1996) The 8th Edition of the table of isotopes, CD-ROM. John Wiley \& Sons, Inc.

Freidlanler B.R., Gochfeld M., Burger J., Powers C.W. (2005) Radionuclides in the marine environment, A CRESP Science Review Draft, 51-52.

Gasco C., Anton M.P., Delfanti R., Gonzalez A.M., Meral J., Papucci C. (2002) Variations of the activity concentrations and fluxes of natural $\left({ }^{210} \mathrm{Po},{ }^{210} \mathrm{~Pb}\right)$ and anthropogenic $\left({ }^{239+240} \mathrm{Pu}\right.$, ${ }^{137} \mathrm{Cs}$ ) radionuclides in the Strait of Gibraltar (Spain), J. Environ. Radioact. 62, 241-262.

HKO (2003) Hong Kong Observatory, Environmental radiation monitoring in Hong Kong, Technical Report no. 22.

IEER (1996) Institute for Energy and Environmental Research, A Special centerfold for technoweenies, A tool kit on natural and a man-made radiation, Vol. 4, No. 1, Takoma Park, MD, USA.

IAEA (1989) International Atomic Energy Agency, Measurement of radionuclides in food and the environment, Technical reports series No. 295, Vienna, Austria.

IAEA (1990) International Atomic Energy Agency, The environmental behaviour of radium, Technical reports series No. 310, Vienna, Austria.

Ito T., Aramaki,T., Kitamura T. (2003) Anthropogenic radionuclides in the Japan Sea: their distribution and transport processes, J. Environ. Radioact. 68, 249-267.

Iyengar M.A.R. (1990) The Natural distribution of radium, The environmental behavior of radium, Technical Reports series No. 310, IAEA, Vol. 1, pp. 9-128.

Jia G., Torri G., Innocenzi P., Ocone R., Di Lullo A. (2006) Determination of radium isotopes in mineral and environmental water samples by alpha spectrometry, J. Radioanal. Nucl. Chem. 267, 505-514.

Keiichi S. (1975) Determination of traces of uranium in Sea water after separation by froth flotation, $J$. Microchem. Acta 63, 313-319.

Kahlos H., Asikainen A. (1980) International radiation doses from radioactivity of drinking water in Finland, Health Phys. 39, 108-111.

Koczy F.F., Tomic E., Hecht F. (1957) Zur geochemie des urans im ostseebecken, Geochim. Cosmochim. Acta 11, 86-102.

Kraemer T. (2003) Uranium and radium in the Sabkha environment: new clues for interpreting the origin of hypersaline brines, Geological Society of America Abstracts with Programs 35, 133.

Lasheen Y. F., Seliman A. F., Abdel-Rassoul A. A. (2007) Simultaneous measurement of ${ }^{226}$ Ra and ${ }^{228} \mathrm{Ra}$ in natural water by liquid scintillation counting, J. Environ. Radioact. 95, 86-97.

Malcome-Lawes D.J. (1979) Introduction to radiochemistry. Unwin Brothers Ltd, Surry.

Matishov D.G., Matishov G.G. (2004) Radioecology in Northern European Seas. Springer, Berlin.

Molero J. (1992) Comportamiento y distrbucion de los radionucleidos de vida larga en ecosisteman marinos. Estudio relativo a radiocesio y a los transuranidos plutonio y americio en el entorno ambiental de la costa mediterranea Espanola. Ph.D. thesis, Coleccion de la Universidad Autonoma de Barcelona.

Padam S., Rana, N., Naqvi A., Srivastava D. (1996) Levels of uranium in water from some Indian Cities determined by fission track analysis, Radiat. Meas. 26, 683-687.

Povinec P.P., Hirose K., Honda T., Ito T., Scott E.M., Togawa O. (2004) Spatial distribution of ${ }^{3}$ H, ${ }^{90} \mathrm{Sr},{ }^{137} \mathrm{Cs}$ and ${ }^{239+240} \mathrm{Pu}$ in surface waters of the Pacific and Indian Oceans-GLOMARD database, J. Environ. Radioact. 76, 113-137.

Ronald M.W. (1998) Over water, the 2nd international Symposium on the treatment of NORM, Krefeld, Germany, November 10-13, Vol. 32. 
Y.F. LASHEEN et al.

Shawky S., Amer H., Nada A.A., Abdel El-Maksoud T.M., Ibrahim N.M. (2001) Characteristics of NORM in the oil industry from Eastern and Western deserts of Egypt, Appl. Radiat. Isot. 55, 135.

Sidhu K.S., Breithart M.S. (1998) Naturally occurring radium-226 and radium-228 in Water Supplies of Michigan, Bull. Environ. Contam. Toxicol. 61, 722-729.

Wernn M.E., Durbin P.W., Howard B., Lipsztein J., Rundo J., Still E.T., Willis D.I. (1985) Metabolism of ingested $\mathrm{U}$ and Ra, Health Phys. 48, 601-633.

WHO (1978) Radiological examination of drinking water, World Health Organization, Copenhagen. 